\title{
Brief Review on Lantana camera
}

\section{Rohit Shankar Mane (iD) 1, Rachana Dattatray Nagarkar 2 ${ }^{2}$ Pragati Pramod Sonawane ${ }^{3}$, Ankala Basappa Vedamurthy (iD**,1}

\author{
${ }^{1}$ Department of Studies in Biotechnology and Microbiology, Karnatak University, Dharwad, Karnataka, 580003, \\ India. \\ 2 Sanjivani Arts, Commerce, Science College Kopargaon, Maharashtra 423603, India \\ ${ }^{3}$ Department of Microbiology, Access Health Care, Pune, Maharashtra, India.
}

\begin{abstract}
Medicinal plants are widely spread in nature with their unique habitats and effective medicinal properties. One of them plant is Lantana Camera. The $L$. camera is well known invasive weed. Used to cure several diseases in Ayurvedic preparations with different formulations. This plant has great ethnobotany and Pharmacology however it is lagging behind in the list of medicinal plants for their applications in drug preparations due to mere research study and awareness. Therefore present review may help to reveal different aspects of $L$. camera with their awareness in society.
\end{abstract}

\section{ARTICLE HISTORY}

Received: February 06, 2019

Accepted: June 09, 2019

\section{KEYWORDS}

Lantana camera,

Ethnobotany,

Pharmacology

\section{INTRODUCTION}

The term "biodiversity hotspot" was coined by the British biologist Norman Myers in 1988. He described them as a biogeographic region by characterizing their exceptional levels of plant endemism and serious levels of habitat loss [1]. Further, in between 1989-1996, Conservation International (CI) adopted 'Myers hotspots criteria' and they made one organization for the reassessment of the hotspots concept and in 2005 they have published an revised title "Hotspots Revisited: Earth's Biologically Richest and Most Endangered Terrestrial Ecoregions" [2]. According to the CI report, there is the total of thirty-five biodiversity hotspots in the world, amongst them, four are in India. Mainly these three biodiversity hotspots are situated in the Himalaya, Indo-Burma, Sundaland, and the Western Ghats. Total 17000-18000 flowering plant species, 8000 medicinal plants, are documented in folk and Ayurveda, Unani, Siddha, and Homoeopathy [3]. Medicinal plants are a great resource base for the traditional medicine $\&$ herbal industry and also it provides livelihood and health security to a large segment of Indian inhabitants. India has the greater natural ecosystem from past two decades, there has

${ }^{*}$ CONTACT: Ankala Basappa Vedamurthy $\varangle$ vedamurthybt@gmail.com $\equiv$ Department of Studies in Biotechnology and Microbiology, Karnatak University, Dharwad, Karnataka, 580003, India 
been a marvelous augment in the use of herbal medicines; though there is still a noteworthy deficiency in the research of medicinal plants and it has the great resources of medicinal plants which are noteworthy to human beings in many ways [4].

According to the World Health Organization, medicinal plants are used as the best resource to obtain a variety of bioactive compounds in the development of different drugs, those are effective as an antimicrobial, anti-tuberculosis, antioxidant, anticancerous, antiinflammatory, antidiabetic, anthelmintic, hepatoprotective activity, larvicidal activity $[5,6]$. One of them plant is Lantana camera, Linn. The word Lantana camera Linn, was derived from the Latin word 'lento' meaning is to bend. Linnaeus first time described and placed them in the binomial system under the family of Verbenaceae. They are present worldwide with the native place America and also obtained from Mexico, Trinidad, Jamaica, Brazil, Florida, Africa, and India. L. camera is regionally differing in their names such as in Marathi: Ghaneri, Hindi: Raimuniya, Tamil: Unnichedi, Kannada: Kakke, Manipuri: Samballei and Telugu: Pulikampa [7]. In India, L. camera is considered as poisonous plant and included in top ten as invasive weeds [8]. Invasive weeds are nothing but a species that is not native to the ecosystem under consideration whose introduction causes economic or environmental harm or to human harm. Due to invasive nature L. camera is lagging behind in the list of medicinal plants for their uses in the drug preparation $[9,10]$.

Therefore the main objective of the present review is to create awareness about ethnobotany and pharmacological studies of L. camera in society.

\section{HISTORY}

L. camera's range extends from Bega Shire in southern NSW to Cape Melville in north Queensland. It is found on the Lord Howe and Norfolk Islands. The chief infestations are east of the huge in-between range in NSW and QLD $[3,4]$.

Pink-edged red lantana grows on the:

1. North Coast around Kempsey, south-east of Dorrigo, Bellingen, in the Coffs Harbour and Grafton areas Central Coast [8].

2. Red varieties grow on the North Coast, around Kempsey, Bellingen and Coffs Harbour.

3. L. camera is improbable to invade new regions in NSW. It is increasing in density and invades new areas within its range [8].

4. L. camera comes from the tropical and subtropical regions of Central and South America. It was introduced to Australia in 1841 as a decorative plant. By the 1860 s it was common in Sydney and Brisbane [16].

3. TAXONOMY $[6,9,14]$

Kingdom: Plantae

Class: Angiosperms

Order: Lamiales

Family: Verbenaceae

Genus: Lantana

Species: L. camera

\section{ECOLOGY}

\subsection{Habit}

L. camera belongs to the family Verbenaceae. It is also known as a red sage. It grows up to 1-3 meter and can spread to 3 meters in width. It is a thorny multistemmed, deciduous shrub. It contains leaves which are opposite, simple, and aromatic, with long petioles, with oval rough 
and hairy blades at margins [2]. Leaves are 3-8 $\mathrm{cm}$ long by 3-6 $\mathrm{cm}$ wide with green color, the pungent smell will emit when it is in crushed condition. Flowers are small, stalked, with different colors such as orange-blue-red-yellow-and bright red flowers. They are dense in the flat-topped cluster with corolla having the narrow tube with the four short spreading lobes. Flowers always go under color changes with weather conditions. Flowering occurs in between March and August [6]. The stem is square in outline, covered with bristly hairs. Roots are dipped in soil up to $50-100 \mathrm{~cm}$. they are yellowish-whitish in color with strong nature. Berries are rounded, fresh, fleshy, poisonous, 2-seeded, initially green-purple in color and finally turns into blue-black color. Berries are attractive to insects and birds due to their attractive nature. It is $6-8 \mathrm{~mm}$ in diameter, round berries, in a group, green to start, shiny, dark purple-black when ripe, and with one seed per fruit $[1,6,7,9]$.

\subsection{Habitat}

L. camera is a tropical origin plant [3]. It requires diverse and broad geographic distribution. It is perennial shrub therefore mainly grows in open, disturbed areas such as roadside, railway tracks, and canals. It establishes at altitudes from the sea level up to $2000 \mathrm{~m}$ and can flourish extremely well under rainfall ranging area from 750 to $5000 \mathrm{~m}$ per annum. It belongs to Central and Northern South America and the Caribbean by birth [6]. It is currently spread in 60 countries. In India, this plant is spread over 7-10 states includes Maharashtra, Himachal Pradesh, Karnataka, Kerala, Uttar Pradesh, Uttarakhand, Gujarat, Rajasthan, Goa, and Arunachal Pradesh [8,11]. They require high sunlight for their growth. They grow in mostly grow in sandy or loamy soil which has $\mathrm{pH} 4$-9. The lowest temperature requires for their growth [12].

Table 1. General Characteristics and habitat of L. Camera

\begin{tabular}{lll}
\hline Sr. No & Parameters & Description \\
\hline 1 & Native & Tropical region in Central and Northern south America \\
\hline 2 & Distribution & Nearly spreaded in 60 countries between $35^{\circ} \mathrm{N}$ and $35^{\circ} \mathrm{S}$ latitude. \\
\hline 4 & Conservation studies & Unknown \\
\hline 5 & Plant colour & Dark green \\
\hline 6 & Plant features & Aromatic, Evergreen, Poisonous \\
\hline 7 & Flowers & Long lasting, small, stalked, with different colors \\
\hline 8 & Tolerances & Wind, slope, pollution, drought, heat and humidity \\
\hline 9 & Pollinators & Lepidopteron species and thrip \\
\hline 10 & Light & High sunlight \\
\hline 11 & pH & 4.5 to 8.5 \\
\hline 12 & Semperature & Below $45^{\circ} \mathrm{C}$ \\
\hline 13 & Water & Sandy to clay \\
\hline
\end{tabular}

\section{ETHNOBOTANY}

L. camera is an important medicinal plant. It has several medicinal applications in the medicinal field. The explants such as leaves, stem, roots, flowers, and seeds are used to extract different bioactive compounds by using different solvents such as water, methanol, ethanol, nButanol [6,7]. Leaves are used to treat cuts, rheumatisms, ulcers, catarrhal infection, tetanus, rheumatism, malaria, cancer, chicken pox, asthma, ulcer, swelling, eczema, tumor, high blood pressure, and bilious fever, ataxy of abdominal viscera, sores, measles, fevers, cold and high 
blood pressure. The whole plant is used to cure bronchitis and the powdered root in milk was given to children for stomach-ache and as a vermifuge. Lantana oil is used to treat a skin infection, itches, and as an antiseptic for wounds $[4,8,11]$.

\subsection{Phytochemistry}

Phytochemistry of $L$. camera has been extensively studied from long back for different applications. The explants of L. camera such as leaves, stem, roots, flowers, and seeds revealed different phytochemicals such as tannin, alkaloids, catechin, steroids, saponins, phenol, anthraquinone, protein, terpenoids, flavonoids, glycosides, different reducing sugars and essential oils. The essential oil consists consist Sabiene, 1,8-Cineole, $\beta$-caryophyllene, $\alpha$ humulene, two are sesquiterpenoids $[2,8,11]$.

Table 2. Used explants for the analysis of Phytochemistry

\begin{tabular}{lll}
\hline Plant & Explants & References \\
\hline \multirow{3}{*}{ Lantana camera Linn. } & Leaves & Sing et al., 1999 \\
\cline { 2 - 3 } & Flowers & Day et al., 2003 \\
\cline { 2 - 3 } & Stalks & Underwood et al., 2003 \\
\cline { 2 - 3 } & Roots & Prasad et al., 2001 \\
\cline { 2 - 3 } & Seeds & Day et al., 2003 \\
\cline { 2 - 3 } & Berries & Thakur et al., 1992 \\
\hline
\end{tabular}

\section{PHARMACOLOGICAL STUDIES}

In India, the Lachhiwala village is situated near to Dehradun around $24 \mathrm{~km}$. The scientists from NGO Himalayan Environmental Studies and Conservation Organization (HESCO) established one lakhs hectors of land with L. camera plants. The village people use L. camera and mud to make the walls of their houses and chicken coops. They are using bark, stems for furniture, trays and baskets purposes. The L. camera leaves have been used to make excellent mosquito repellents and incense sticks. Such innovative use of the weed brings in Rs 75,000 a year for each of the families there therefore they have named village name as a Lantana village. All lantana villagers are using this L. camara plant for economic purposes [6,9].

\subsection{Antimicrobial Activity}

Different extracts of L. camara explants are used against different microorganisms such as bacteria and fungi. The explants such as leaves, stem, roots, flowers, and seeds extracts revealed effective Phytochemistry and their useful applications against different microorganisms. Aqueous, ethanol and methanol extracts of leaves, roots stem, and flowers of L. camara showed effective antibacterial activity against E. coli, Proteus vulgaris, Vibrio cholareae, Bacillus subtilis, P. aeruginosa and Staphylococcus aureus by disc diffusion and micro dilution method [2,4,7,9]. Further antifungal activity of $L$. camara extract was screened against Alternaria species which causes dissimilar plant diseases in vegetable plants. The activity was performed by food poison plate method at three different concentrations of extract viz, $10 \mathrm{mg} / \mathrm{ml}, 15 \mathrm{mg} / \mathrm{ml}$ and $20 \mathrm{mg} / \mathrm{ml}$. At $20 \mathrm{mg} / \mathrm{ml}$ dose L. camara exhibited significant antifungal activity against Alternaria species. Both extracts exhibited well-organized antifungal activity against white and brown rot fungi, however ethanol extract was highly potential at very low concentration $(0.01 \%)$ therefore it is concluded that $L$. camara has effective antimicrobial activity [9-11]. 


\subsection{Antimotility activity}

L. camara has great antimotility activity which was proved by the report of leaves methanol extract antimotility activity in mice. $1 \mathrm{~g} / \mathrm{kg}$ body weight dose was used to check the intestinal motility by charcoal meal test in mice which resulted into completely inhibition and Intraperitoneal management of 125 and $250 \mathrm{mg} / \mathrm{kg}$ body heaviness the extracts considerably reduced the fecal production in castor oil induced diarrhoea in mice [1-3].

\subsection{Antiulcerogenic activity}

Antiulcerogenic activity of the methanol extract of leaves of L. camara was reported on aspirin, ethanol and cold resistant stress induced gastric lesions in rats. Pre-treatment of the effected rats with the extract ( 200 and $400 \mathrm{mg} / \mathrm{kg}$ body weight) showed noteworthy defensive effect in aspirin induced, ethanol induced and cold restraint stress induced ulcers in rats. The extract resulted in dose dependent antiulcerogenic activity in all models [4-6].

\subsection{Hemolytic activity}

The hemolytic activity of $L$. camara aqueous extract and their solvent fractions was performed by spectroscopic method with different concentrations such as 125, 250, 500, 1000 $\mu \mathrm{g} / \mathrm{ml}$ which was resulted into very low hemolytic activity towards the human erythrocytes $[7,8]$.

\subsection{Antihyperglycemic activity}

Different extracts of L. camara has been proved effective and digestive antihyperglycemic activity. Extracts includes methanol extract of leaves, aqueous extract of roots. These both extracts were reported in alloxan induced diabetic rats. Oral administration of the methanol extract of $L$. camara $(400 \mathrm{mg} / \mathrm{kg}$ body weight) leaves revealed decreased blood glucose up to $121.94 \mathrm{mg} / \mathrm{dl}$. Extract action also showed development in body weight, HbAlc profile as well as renewal of liver cells $[6,8,16]$.

\subsection{Wound healing activity}

Wound healing activity of aqueous leaves extract of L. camara was reported in rats. 100 $\mathrm{mg} / \mathrm{kg} /$ day of dose significantly enhanced the rate of wound contraction (98\%), synthesis of collagen and decreased wound healing occasion. Then ethanol extract of leaves of L. camara was also reported for wound healing activity in adult male Wister rats. Histological analysis of healed wounds established the role of take out in healing $[5,16]$.

\subsection{Antiinflammatory activity}

Anti inflammatory activity of aqueous extract of L. camara was reported in albino rats. The $500 \mathrm{mg} / \mathrm{kg}$ body weight significantly decreased paw volume in carrageenan induced paw oedema rat tests $[11,12]$.

\subsection{Antiurolithiasis activity}

Different extracts of the L. camara leaves was reported for antiurolithiasis activity against ethylene glycol and ammonium chloride induced calcium oxalate urolithiasis in male albino rats which revealed significant reduction of the deposition of calcium, oxalate and also reduced urinary excretion of calcium, oxalate and creatinine [12,13].

\section{CONCLUSION}

Lantana camara is the poisonous, invasive, a noxious weed, present worldwide however due to insufficient knowledge and myths weed is lagging behind in the list of medicinal plants. The Ethanopharmaceutical and pharmacological studies revealed different aspects of Lantana camara therefore present study may helpful to create awareness in society about the plant. 


\section{Acknowledgements}

We are great full to Professor and Vice chancellor Dr. P. B. Gai, Karnatak University, Dharwad, for extended facilities.

\section{Orcid}

Rohit Shankar Mane (iD https://orcid.org/0000-0002-4694-6681

Ankala Basappa Vedamurthy (DiD https://orcid.org/0000-0002-3101-0629

\section{REFERENCES}

[1] Achhireddy, N.R., Singh, S.M., Achhireddy, L.L., Nigg, H.N., Nagy, S.S. (1985). Isolation and partial characterization of phytotoxic compounds from Lantana (Lantana camara L.). Jour. Chem. Eco, 11, 979-988.

[2] Begum, S., Wahab, A., Siddiqui, B.S. (2000). Pentacyclic triterpenoids from the aerial parts of Lantana camara. Chem. Pharm. Bul, 51, 134-137.

[3] Bhatt, N., Gupta, P.K., Naithani, S. (2011). Ceric-induced grafting of Acrylonitrile onto Alpha Cellulose isolated from Lantana camara. Cell. Chem. Techn, 45, 321-327.

[4] Bhatt, Y.D., Rawat, Y.S., Singh, S.P. (1994). Changes in ecosystem functioning after replacement of forest by Lantana shrubland in Kumaon Himalaya. Jour. Veg. Sci, 5, 6770.

[5] Chopra, R.N., Nayar, S.L., Chopra, I.C. (1956). Glossary of Indian medicinal plants. CSIR New Delhi, India.

[6] Day, M.D., Wiley, C.J., Playford, J.J., Zalucki, M.P. (2003). Lantana: Current Management, Status and Future Prospects. Aust. Cen. Inter. Agri. Res, 5, 1- 20.

[7] Ganjewala, D.D., Sam, S., Khan, K.H. (2009). Biochemical compositions and antibacterial activities of Lantana camara plants with yellow, lavender, red and white flowers. Eur. Jour. Bio., 3, 69-77.

[8] Kensa, V.M. (2011). Studies on phytochemical screening and antibacterial activities of Lantana camara Linn. Pl. Sci. Fe., 1, 74-79.

[9] Kalita, S. (2011). Phytochemical composition and in vitro hemolytic activity of Lantana camara L. (Verbenaceae) leaves. Pharmacologyonline, 1(7), 59-67.

[10] Prasad, A.M., Iverson, L.R., Liaw, A. (2006). Newer classification and regression techniques: bagging and random forests for ecological prediction. Eco., 9, 181-199.

[11] Sharma, S., Singh, A., Sharma, O.P. (1999). An improved procedure for isolation and purification of lantadene A, the bioactive pentacyclic triterpenoid from Lantana camara leaves. Jour. Medi. Aro. Pla. Sci., 21, 686-688.

[12] Thakur, M.L., Ahmad, M., Thakur, R.K. (1992). Lantana weed (Lantana camara var. aculeata Linn) and its possible management through natural insect pests in India. Ind. Fors, $118,466-488$.

[13] Tucker, C.J. (1979). Red and photographic infrared linear combinations for monitoring vegetation. Jour. Re. Sen. Envir, 8, 127-150.

[14] Underwood, E., Ustin, S., DiPietro, D. (2003). Mapping nonnative plants using hyperspectral imagery. Rem, Sens, Envir, 86, 150-161.

[15] Yang, X., Skidmore, A.K., Melick, D.R., Zhou, Z., Xu, J. (2007). Towards an efficacious method of using Landsat TM imagery to map forest in complex mountain terrain in Northwest Yunnan, China. Tro. Eco., 48, 227-239.

[16] Zhang, M., Liu, X., O'Neill, M. (2002). Spectral discrimination of Phytophthora infestants infection on tomatoes based on principal component and cluster analyses. Int., Jou., Rem., Sens., 23, 1095-1107. 